\title{
IMPACT OF FOREIGN INSTITUTIONAL INVESTMENT ON INDIAN STOCK MARKET
}

\author{
Dr. H N Shivprasad \\ Director, \\ REVA Institute of Management studies, \\ Bangalore
}

\begin{abstract}
India, after United States hosts the largest number of listed companies. Global investors now ardently seek India as one of their preferred location for investment. Many Indians working in foreign countries now divert their savings to stocks. This recent phenomenon is the result of opening up of online trading and diminished interest rates from banks. The major portion of investment in Indian markets is always attributed to the institutional players amongst whom the foreign institutional investors are of primary significance.
\end{abstract}

The present study covers FII investment into equity. The period of the study was from January 2006 to January 2013. This period of study captured both the bearish and bullish trends. The study will provide a very clear picture of the impact of foreign institutional investors on Indian stock indices

The objective of the present study it's identifying whether there exist a causal relationship between net investment made by FII's and the equity return in the Indian Stock Market. In order to check the relationship between foreign institutional investment and stock returns in India, the data for net FII investments and stock returns (BSE) during January 2006 and January2013have been used in this study. The relationship has been checked by conducting the Augmented Dickey Fuller Test(ADF),Phillips-Perron(PP) Test and the Granger causality test.

Key words - Granger Ca u s a lity, FII Investment

\section{Introduction}

Foreign investment refers to the investments made by the residents of a country in the financial assets and production processes of another country. The causes and benefits from such foreign investment, however, vary from country to country. Foreign Investment can persuade the factor productivity of the recipient country and also shape the balance of payments. In developing countries like India there has been a felt need for foreign capital, not only to boost the productivity of labour but also to help to building up the foreign exchange reserves needed to meet our trade deficits. Foreign investments provide a direction through which developing countries can gain access to foreign capital for their economic development. Foreign Investment can come in two ways: foreign direct investment (FDI) and foreign institutional investment (FII). Foreign Direct Investment involves direct production activities of a medium to long-term in nature. But, foreign institutional investment is a short term investment avenue, mostly in the financial markets.

India, being a capital scarce country, opened her doors to foreign institutional investors in September, 1992 to attract foreign investments. This event symbolized a landmark experience resulting in successfully globalizing its financial services industry. Originally pension funds, mutual funds, investment trusts, asset management's companies and incorporated/institutional portfolio managers were permitted to invest directly in the Indian stock markets. Beginning 1996-97, the group was further expanded to incorporate registered university funds, endowment funds, foundations and charitable trusts. Since then, FII form a 
major part of foreign portfolio investments in Indian markets.

In the aftermath of 1997 East Asian crisis, FII flows had actually become the net outflows in 1998-99. But there was a modest recovery in 1999-2000. FII flows further steadily declined to US \$377 million in 2002-03. This resulted in the decline of BSE Sensex by 161.85 points from January 2003 to May 2003 (India Budget, 2005).

However, the years 2003-04 and 2004-05, have been remarkably robust years for FII flows. The movement of Sensex during these two years were evidently been driven by the actions of FIIs. They were responsible for net equity purchases of as much as $\$ 6.6$ and $\$ 8.5$ billion during 2003 and 2004 respectively. This indicates the significant contribution made by FIIs in Indian stock market. This contribution made by foreign investors witnessed a rise in Sensex to 6676 (on January 3,2005) from 2924 (on April 5,2003) (Hindu Business Line,2005).During 2007 alone FIIs made a net investment of about \$17 billion in Indian stock markets, which is nearly 10 times higher than the domestic mutual fund's net investment (Economic Times). These figures show the importance of foreign investment in the overall investment programme of Indian equity market.

As per data from Indian market regulator SEBI, foreign institutional investors (FIIs) pumped in more than $\$ 24$ billion into Indian stocks during the year 2012. Quantitative easing around the world, and various policy reforms by the Indian government announced in the second half of the year led to large inflows into Indian stocks. This is the second highest FII inflow registered in a calendar year into the Indian stock markets. The highest FII inflow was recorded in calendar year 2010 (of more than $\$ 29$ billion).

The net FII Investments are presented in the following Table.1

\begin{tabular}{|l|l|}
\hline Year & Rupees invested (in crores) \\
\hline 2005 & 47,182 \\
\hline 2006 & 36,540 \\
\hline 2007 & 71,486 \\
\hline 2008 & $-52,987$ \\
\hline 2009 & 83,424 \\
\hline 2010 & $1,33,266$ \\
\hline 2011 & $-2,714$ \\
\hline 2012 & $1,28,360$ \\
\hline
\end{tabular}

The Sensex figures for the period 20062012 are given in Table. 2

\begin{tabular}{|l|l|l|}
\hline Year & $\begin{array}{l}\text { Sensex } \\
\text { OPEN }\end{array}$ & $\begin{array}{l}\text { Sensex } \\
\text { CLOSE }\end{array}$ \\
\hline 2006 & 9422.49 & 13786.91 \\
\hline 2007 & 13827.77 & 20286.91 \\
\hline 2008 & 20325.27 & 9647.31 \\
\hline 2009 & 9720.55 & 17464.81 \\
\hline 2010 & 17473.45 & 20509.09 \\
\hline 2011 & 20621.61 & 15454.92 \\
\hline 2012 & 15534.67 & 19426.71 \\
\hline
\end{tabular}

\section{OBJECTIVE OF THE STUDY}

The objective of the present study is to identify whether there exist a causal relationship between net investment made by FII's and the equity return in the Indian Stock Market. In order to check the relationship between foreign institutional investment and stock returns in India, the data for net FII investments and stock returns (BSE) during January 2006 and 
January2013have been used in this study. The relationship has been checked by conducting the Augmented Dickey Fuller Test (ADF),Phillips-Perron(PP) Test and the Granger causality test.

\section{LITERATURE RIVIEW}

There are many studies on foreign investment and stock market related topics. This section deals with the review of such studies.

Agarwal (1997) studied the impact of foreign portfolio investment (FPI) on the national economy of six developing economies of Asian countries (including India). They show through regression results that inflation rate, real exchange rate, index of economic activity and the share of domestic capital market in the world stock market capitalization are the four statistically significant determinants of foreign portfolio investment flow.

Chakrabarti and Vimal (2001), concluded in their study that in the pre-Asian crisis period any change in FII was found to have a positive impact on the equity returns, whereas in the post-Asian crisis the reverse relationship was noticed. FII's accounted for amajor portion of investments and their roles in determining the movement of share price and indicesis considerably high. The movement of indices in India depends only on the trade done in limited number of stocks. Thus, when the FII's frequently buy and sell stocks, it leads to volatility of the market.

The study conducted by Gordon and Gupta (2002) on portfolio flows into India and the influence of domestic fundamental factors, found that there is strong impact of domestic fundamentals on the portfolio flows into India. They used the monthly equity flows from September 1992 till October 2001 and applied regression model and unit root test. In their study they concluded that the portfolio flows to India are small, compared to other emerging markets and also less volatile than other emerging markets. The combination of domestic, regional and global variables are important for determining the portfolio flows into India.

Mukherjee (2002)examined the determinants of FII and concluded that (1) Foreign investment flows to the Indian markets tend to be caused by return in the domestic equity market; (2) returns in the Indian equity market is an important factor that has an impact on FII flows; (3) whereas FII sale and FII net inflow are significantly affected by the performance of the Indian equity market, FII purchase show no such affect to this market performance; (4) FII investors do not 
probably use Indian equity market for the purpose of diversification of their investment; (5) returns from the exchange rate variation and the fundamentals of the economy may have an impact on FII decisions, but such influence have not proved to be strong enough.

Raj Chaitanya (2003),in his research work titled 'Foreign Institutional Investments' discussed in length about the FIIs and their impact on the Indian economy. Analyzing daily flow data, he concludes that the stock market performance has been the sole driver of FII flows, though monthly data in the pre-Asian crisis period suggests some reverse causality.

Agarwal, Chakrabarti et al (2003) have found in their research that the equity return has a significant and positive impact on the FII. But given the huge volume of investments,

foreign investors could play a role of market makers and book their profits, i.e., they can buy financial assets when the prices are declining thereby jacking-up the asset prices and sell when the asset prices are increasing. Hence, there is a possibility of bi-directional relationship between FII and the equity returns.

Batra, A (2004)in his researchworkhas analyzed the trading behaviour of FIIs and their impact of trading biases upon stock market volatility. It was found that there is a strong evidence for the fact that FIIs on daily basis have been positive investors and trend chasers at the aggregate level. But there seem to exist no evidence of positive feedback trading on monthly basis. The research work also indicates that the foreign investors have a tendency to herd together in their trading activity in India. The trading behaviour/biases of the FIIs do not appear to have a destabilizing impact on the equity market.

The study conducted by David and Steil (2004) viewed that the macroeconomic factors like current account surplus, accretion in foreign exchange reserves, appreciating domestic currency and higher interest rates have been responsible for an increase in FII inflows to an emerging country.

Pal, P. (2004)found that FIIs are the major players in the Indian stock market and their impact on the domestic market is increasing. Trading activities of FIIs and thedomestic stock market turnover indicates that FII's are becoming more important at the margin as an increasingly higher share of stock market turnover is accounted for by FII trading in India.

\section{METHODOLOGY}

From the above research reviews, it can be concluded that research findings 
support the existence of bi- directional relationship between the FII investments and stock market returns. Though few research papers have used the Granger-causality test to confirm the direction of causality between FIIs and mutual funds or firm levels, it has not yet been established whether the FII investments can be attributed to causing the market condition or it is the reverse. Hence, in this paper an attempt has been made to analyze the causal relationship between the net FII investment and equity returns. The study has been conducted using the Augmented Dickey Fuller Test (ADF), Phillips-Perron (PP) Test and the Granger-Causality test.

For the study two hypotheses have been formulated. The prime intention is to test the causality between net FII investment and equity returns. Accordingly the first hypothesis is "Net FII investments does not Granger- cause Sensex returns" and the second one being, "Sensex returns does not Granger- cause Net FII Investment”.

First Hypothesis

$\mathrm{H}_{0}$ : FII Investment does not Grangercause Sensex return

$\mathrm{H}_{1}$ : FII Investment Granger-causes Sensex returns

\section{Second Hypothesis \\ $\mathrm{H}_{0}$ : Sensex Return does not Granger- Cause FII Investment \\ $\mathrm{H}_{1}$ : Sensex Return causes FII Investment}

\section{DATA FOR THE STUDY}

The analysis was carried out using the daily stock market data and net investment data of FII for the period from January 4, 2006 to January 31,2013 . The results from the daily data considered are better and more precise to capture the lead lag dynamics between net investments by FII's and equity returns. The stock returns arecalculated for BSE Sensex Data values.

The data for Sensex has been taken from BSE website (www.bseindia.com). The data for FII's investment is taken from the moneycontrol website

(www.moneycontrol.com).

The equity returns are calculated on the basis of logarithm method of two days price change.

$\mathrm{R}_{\mathrm{t}}=\mathrm{LN}\left(\mathrm{P}_{\mathrm{t}} / \mathrm{P}_{\mathrm{t}-1}\right)$

In the above equation, 
- Rt represents return at time $t$,

- $\mathrm{LN}$ is the natural logarithm.

- Pt represents Closing Sensex value at time, $\mathrm{t}$.

- Pt-1 represents previous day's Sensex Closing value ( $\mathrm{t}-1)$.

No trading days are omitted and the equity price change is calculated from the last trading day when the market was open. FIIs investments in Indian currency (rupee) are used for the analysis. The Sensex value and the net FII investment in equity market is taken from January 2006 to January 2013. The 7 years data is taken as a basis to calculate the relationship between the Foreign Institutional Investment and the Indian Sensex.

\section{DATA ANALYSIS INTERPRETATION}

As outlined in the methodology, the Granger- Causality tests have been carried out for the data points between net foreign investment inflows and equity returns in the Indian market for the time period between January 2006 and January 2013. This period has been considered because of the fact that from January 2006 Sensex crossed 6000 marks and climbed further to touch 21000 in January 2008 (The Hindu, 2008). And further the Sensex came down to around 8000 in the year 2009 and then gradually went on increasing with some flexibilities in the coming year. This seven year data can help to analyse about the reasons related to rise and fall in the Sensex and the impact of Foreign Institutional Investors over it. The cyclicaltrend in Indian equity market may be because of the foreign investor's active participation or the Indian strong fundamental factors caused by stock return attracted the foreign investors into our equity market.

To see this cause and effect of foreign institutional investments and Indian stock market (Sensex) return, the present study has been undertaken. There are 1750 data points each for FII and market returns have been considered for the study.

In order to test whether the series is stationary or not the Unit root test has been conducted. As mentioned earlier, there are two methods to conduct a unit root test; Augmented Dickey Fuller (ADF) test and Phillips- Perron (PP) test. The results for the unit root tests conducted by the two techniques are interpreted below:

The ADF test statistics for the FII investments and Sensex return is presented in Table 3 and Table 4respectively. The result show that the ADF statistic is 11.21276 for FIIs and -39.08578 for Sensex.Both the ADF values for the FII and 
Sensex are less than the MacKinnon (1996) critical values for rejection of hypothesis of a unit root at $1 \%, 5 \%$ and $10 \%$ level of significance. This proves that both the net FII investment and Sensex return series are stationary.

Table 3A:ADF Test Statistics for FII Investment

\begin{tabular}{llll}
\hline \hline & & t-Statistic & Prob.* \\
\hline \hline Augmented Dickey-Fuller test statistic & -11.21276 & 0.0000 \\
\hline Test critical values: & 1\% level & -3.433910 & \\
& 5\% level & -2.862999 & \\
& $10 \%$ level & -2.567594 & \\
\hline \hline
\end{tabular}

*MacKinnon (1996) one-sided p-values.

Table 3B:ADF Test Statistics for Sensex Returns

\begin{tabular}{lccc}
\hline \hline & t-Statistic & Prob.* \\
\hline \hline \multicolumn{2}{l}{ Augmented Dickey-Fuller test statistic } & -39.08578 & 0.0000 \\
\hline Test critical values: & 1\% level & -3.433888 & \\
& 5\% level & -2.862990 & \\
& 10\% level & -2.567589 & \\
\hline \hline
\end{tabular}

*MacKinnon (1996) one-sided p-values.

The Phillips-Perron (PP) test statistics for the FII investments and Sensex returns is presented in Table 3 and Table 4 respectively. The results show that the PP statistic for FII is -35.31575 whereas for Sensex return is -39.01818 . Both the values are lesser than the Mackinnon (1996) critical values for rejection of hypothesis of a unit root at $1 \%, 5 \%$ and $10 \%$ level of significance. This proves that the FII investment is stationary in nature.

Table 4A: PP Test Statistics or FII Investment

\begin{tabular}{lcc}
\hline \hline & Adj. t-Stat & Prob.* \\
\hline \hline Phillips-Perron test statistic & -35.31575 & 0.0000 \\
\hline Test critical values: $1 \%$ level & -3.433892 & \\
5\% level & -2.862991 & \\
10\% level & -2.567590 & \\
\hline \hline
\end{tabular}

*MacKinnon (1996) one-sided p-values. 
Table 4B: PP Test Statistics for Sensex Returns

\begin{tabular}{lrl}
\hline \hline & Adj. t-Stat & Prob. $^{*}$ \\
\hline \hline Phillips-Perron test statistic & -39.01818 & 0.0000 \\
\hline Test critical values: $1 \%$ level & -3.433888 & \\
5\% level & -2.862990 & \\
10\% level & -2.567589 & \\
\hline \hline
\end{tabular}

*MacKinnon (1996) one-sided p-values.

Thus the above two tests confirm that the FII investment and Sensex return data series are stationary in nature. The detection of causal relationship between the two stationary data series have been conducted by applying the Granger- Causality test. The results of the Granger- Causality test are presented in Table 5.The results reveal that the FII investments cause the Sensex return whereas the reverse is not true. Hence the conclusion that can be drawn is that the FII investments Granger- Cause Sensex return.

Table 5: Granger-Causality Test Statistics

\begin{tabular}{lccc} 
Null Hypothesis: & Obs & F-Statistic Prob. \\
\hline \hline FII does not Granger Cause SENSEX_RETURN & 1744 & 0.09287 & 0.9113 \\
SENSEX_RETURN does not Granger Cause FII & & & \\
\hline \hline
\end{tabular}

\section{FINDINGS AND CONCLUSION}

The basic purpose of the study was to determine whether there exists any bidirectional relationship between FII investments and Sensex returns. To achieve this purpose the FII and Sensex data had been taken from January 2006 to January 2013 for analysis.

The unit root test was used to test the Stationarity of the data series used for the purpose of analysis. The unit root test is conducted by Augmented Dickey-Filler Test and Phillips-Perron Test. The tests were conducted for both the series under consideration i.e. FII investments and Sensex returns. The ADF and PP test statistics for FII investments and Sensex returns clearly reveal that both the series are stationary, which is a necessary condition for the Granger- Causality Test.

On these stationary data series the GrangerCausality Test is conducted. The test considers two hypothesis which accounts for the bi-directional relationship between FII investments and Sensex returns. It basically checks the causality between the two series i.e. whether the FII cause Sensex returns or vice versa? The test statistics accept the null hypothesis which says that Sensex return does not cause FII investments and reject the null hypothesis which says that FII investment do not cause Sensex return. Hence it is proved that FII investments cause Sensex returns. 
The results of the tests conducted reveal that the flow of FII investments seems to have an influence on the Indian stock market. This apparent unidirectional relationship is confirmed by the Granger- Causality Test.

It is quite likely that the causality running from the FII's to equity returns is being averaged out on the Sensex index level only, but may exist and be more prominent at the individual stock level. Also as the information on FII trades is available to different parties in the market at different points of time, its impact even if weak, is spread over to couple of days.

There may be a scope for the further study of more detailed disaggregated analysis at individual stock level which may statistically validate the bi-directional relationship over the sample period.

\section{REFERENCES}

[1] Agarwal, R.N. (1997), "Foreign portfolio investment in some developing countries: A study of determinants and macroeconomic impact",Indian EconomicReview, Vol,32, Issue 2, pages 217-229.

[2] Ananthanarayanan Sandhya, Chandrasekhar Krishnamurti and Sen Nilanjan (2005), "Foreign Institutional Investors and Security Returns: Evidence from IndianStock Exchanges" Conference paper at CAF, ISB, Hyderabad, Dec 21-22.

[3] Ambuj Gupta,(2011), "Does the stock market rise or fall due to FIIs in India"International Referred Research Journal, April.

[4] Anubha Shrivastav (2013), "Study A of Influence of FII Flows on Indian Stock Market", GYANPRATHA-ACCMAN, Journal of Management, Volume 5 Issue 1.
[5] Batra, A (2004) "Foreign Institutional Investors: An Introduction", ICFAI University Press, pages -107-111.

[6] Bhupender Singh (2005), "Inter Relation between FII, Inflation and Exchange Rate", Journal of Institutional Investors, Vol 17. Publisher: Emerald Group Publishing Limited

[7] Chakrabarti, Rajesh(2001), "FII Flows to India: Nature and Causes."

MoneyandFinance"Vol.2,No.7, October-December,pages 61-81.

[8] Chakrabarti and Vimal (2001)," Stock Return Volatility Patterns in India"

<http://www.networkideas.org/feata rt/nov2004/Volatility_Stock_Market $\mathrm{s}$

[9] David,E.P.,\&Steil,B.(2004), "Institutional Investors", Cambridge Mass: MIT Press, Pages 225-265.

[10] Dash Ranjan Kumar and Singh Sumanjeet(2008), "Is Indian Stock Market MoreVolatile in Reform Period? Evidence fromE-GARCHModel", The ICFAI Journal of Applied Economics, Vol.7, No.1, July, pages 61-69.

[11] Dhwani Mehta (2009),"A Study: FII Flows in India", Research on Indian StockVolatilty . Vol 14. Publisher: Emerald Group Publishing Limited.

[12] Dickey David A, and Wayne A, Fuller (1979), "Distribution of the Estimators for Auto regressive time series with aUnitroot", Journalofthe AmericanStatisticalAssociation, Vol.74, No.366, June,pages 427431

[13] Gordon, James and Poonam, 
Gupta

(2002),

"PortfolioFlowsintoIndia: Do

DomesticFundamentals

Matter?"

Presentation

atNCAER, October 22.

[14] Granger,C.W.J (1969),

"Investigating CausalRelations

by Econometric Models

andCross-spectral Methods",

Econometrica, Vol.37, No.3,

August, pages 424-438.

[15] Khan Masood Ahmad, Shahid Ashraf andShahid Ahmed (2005), "An EmpiricalInvestigation of FIIs role in the Indian equity market A firm level analysis",Icfai Journal of Applied Finance,Vol.2,No.8, Sept, pages 21-23.

[16] K.K.Ray (2009). "Foreign Institutional Investment Flow and Indian Stock Market Returns: A Relationship Study" Vilakshan, XIMB Journal of Management, March, pages 39-58.

[17] Krishna Reddy Chittedi (2009). " Volatility of Indian Stock Market and FIIs", Journal: European Business Review. Vol 15, pages 22 $-34$

[18] Kulwantraj N. Bindu (2004)."A study on: The determinants of foreign Institutional Investments in India and the role of risk, inflation and return", Indian Economic Review, Vol, 32, Issue 2, pages 217229.

[19] Kumar, Vijay Chandra C. (2006), "Foreign InstitutionalInvestors: AnIntroduction”, IcfaiUniversity Press, pages-107-111. 